\title{
Информациона писменост наставника и сарадника на Универзитету у Београду
}

\author{
Гордана Стокић Симончић \\ Универзитет у Београду \\ Филолошки факултет - Катедра за библиотекарство и информатику, Београд
}

gordana.stokic.simoncic@gmail.com

Драгана Сабовљев

Градска народна библиотека „Жарко Зрењанин“, Зрењанин

dragana.sabovljev@gmail.com

\begin{abstract}
Сажетак
У раду су представљени резултати истраживања које је спроведено током 2017. године на Универзитету у Београду, а имало је за циљ да утврди ниво информационе писмености наставника и сарадника, испитујући њихову оспособљеност за руковање истраживачким подацима. Истоветном онлајн анкетом (Вештина коришћења података и управљање истраживачким подацима - Data Literacy and Research Data Management Research) прикупљани су подаци о навикама истраживача (професора, сарадника, докторанада, библиотекара), у академским срединама већег броја европских држава упоредо, да би се омогућило компаративно сагледавање проблематике.

Узорак од 85 испитаника потврдио је полазну претпоставку анкетара да ниво информационе писмености наставника и сарадника на Универзитету у Београду треба систематски унапређивати. Но, показао је и мањак институционалне инфраструктуре (политике, сервиси, средства, репозиторијуми, процедуре), па и недостатак, односно непознавање стручне терминологије у области управљања истраживачким подацима, што све заједно директно утиче на ефективност научног процеса.
\end{abstract}

Кључне речи: Универзитет у Београду, наставници, сарадници, истраживачи, библиотекари, навике, информациона писменост, анкета, Вештина коришћења података и управљање истраживачким подацима - Data Literacy and Research Data Management Research, инфраструктура

\section{Увод}

Као што је мало познато да се рачунарска технологија, прешавши из војне у цивилну употребу, најпре настанила у библиотекама (прво Сједињених Америчких Држава), тако се ретко истиче и да су библиотекари, као професионална групација, први почели да указују на кризу у начину учења, усвајања нових знања, анализе, синтезе и размене података, као последицу информатизације друштва експоненцијалног пораста броја информација те информационих канала и севиса у последњој четвртини 20. века. ${ }^{1}$ Професионалне асоцијације попут ALA-e и IFLA-е ${ }^{2}$ прве су указале на овај глобални проблем, дефинисале га и у свом окриљу развиле модалитете за његово ублажавање, а информационо описмењавање означиле као императив нашег времена и једну од легитимних обавеза савремених библиотечко-информационих стручњака.

\footnotetext{
1 Рад је написан у оквиру пројекта Диїишалне меgијске шехнолоїије и ярушйвено-образовне йромене, број 47020, Министарства за науку и технолошки развој Републике Србије.

2 Америчка библиотечка асоцијација је још 1989. године формулисала данас веома широко прихваћену дефиницију према којој су информационо писмени они појединци који су научили како треба учити, јер знају како је људско знање организовано, како пронаћ праве информације и како их ефикасно користити. - ALA Presidental Committee on Information Literacy, Final Report (1989), http:// www.ala.org/acrl/publications/whitepapers/presidential (preuzeto 24. 12. 2017). Међународна федерација библиотечких удружења и институција - IFLA је низом својих декларација (почев од 2003) трасирала пут промовисању овог концепта, те је створена и засебна Секција за информациону писменост (Information Literacy Section, https://www.ifla.org/information-literacy (preuzeto 15. 11. 2017).)
} 
„Иако се с правом може рећи да је информационо описмењавање важно за целокупну популацију корисника савремених библиотека, овај процес посебно је важан за оне кориснике чији професионални статус зависи од квалитета и брзине пронађених информација, попут студената или научних радника. Полазећи од раније наведене дефиниције информационе писмености, ${ }^{3}$ наводимо неколико суштинских задатака њиховог оспособљавања за активно коришћење библиотечких ресурса у електронском окружењу: идентификација информационих потреба, одабир релевантних информација, формулисање питања за претраживање, разликовање популарних и научних извора информација, разликовање примарних и секундарних информационих ресурса, коришћење Булових оператора у претраживању, одабир стратегија за претраживање база података, разумевање проблема сувишка информација, критичко коришћење информационих извора, организовање и преношење пронађених информација, коректно цитирање коришћених извора и разумевање ауторских права на интернету, спремност за доживотно учење". ${ }^{4}$

Оспособљеност за руковање истраживачким подацима, односно проналажење, вредновање и коришћење података (како описно може да се преведе енглеска синтагма data literacy) постала је кључна компонента савременог научног истраживања. ${ }^{5}$ Соња Шпиранец с правом истиче да се она може посматрати као проширење информационе писмености од пресудне важности за научну заједницу која заступа концепт отворене науке као савремени тренд, ${ }^{6}$ док Тибор Колтај указује да је образовање у овом релативно новом подручју потребно како библиотекарима, тако и истраживачима свих профила, а нарочито онима у домену хуманистичких и друштвених дисциплина. ${ }^{7}$

У оквиру Европске конференције о информационој писмености ${ }^{8}$ поникла је идеја о опсежном истраживању навика истраживача (професора, сарадника, докторанада, библиотекара) у академским срединама, да би се омогућило компаративно сагледавање проблематике.

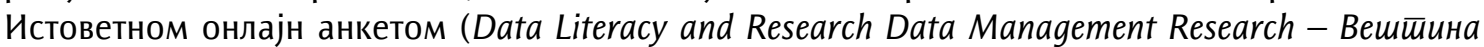

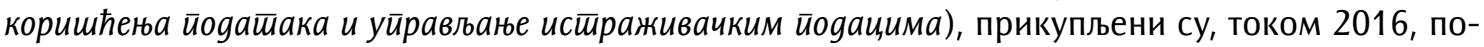
даци из Велике Британије, Француске и Турске, ${ }^{9}$ док је 2017. године, у већем броју европских земаља, обављено исто истраживање. Овај рад представља резултате добијене истраживањем академског простора Универзитета у Београду.

\section{Навике истраживача на Београдском универзитету}

Развој Универзитета у Београду може се пратити од 1808. године. Данас је то заједница од око 5000 наставника (око 2500 редовних, ванредних професора и доцената и још толико асистената и других сарадника у настави) и преко 90.000 студената. Универзитет чини 31 организациона јединица, односно факултети разврстани према научним пољима у групације: 1) друштвено-хуманистичких наука (10 факултета); 2) медицинских наука (4 факултета); 3) природно-математичких наука (6 факултета) и 4) техничко-технолошких наука (11 факултета).

3 „Informaciona pismenost osposobljava ljude da uče tokom celog života i da budu uspešni u dinamičnom okruženju visokih informacionih tehnologija." - Sonja Špiranec i Mihaela Banek Zorica, Informacijska pismenost - Teorijski okvir i polazišta (Zagreb: Zavod za informacijske studije, 2008)

${ }^{4}$ Gordana Stokić Simončić i Željko Vučković, „Information Literacy in Serbia: Initiatives and Strategies", Studies in Informatics and Control (SIC) Volume 19, number 2 (June 2010): 177-184.

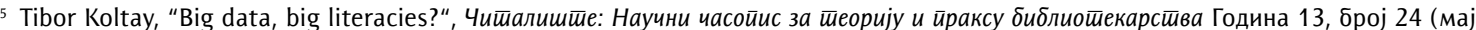
2014): 3-8

${ }^{6}$ Sonja Špiranec and Denis Kos, "Data Literacy and Research Data Management: the Croatian State of Affairs", In ECIL 2017, CCIS, S. Kurbanoğlu et al., eds. (Heidelberg: Springer Verlag), 5. Dostupno i na http://link.springer.com/ (preuzeto 9. 3. 2018).

7 Tibor Koltay, Nav. delo.

${ }^{8}$ ECIL - European Conference on Information Literacy.

9 Gobinda Chowdhury et al., "Preparedness for Research Data Sharing: A Study of University Researchers in Three European Countries". In Digital Libraries: Data, Information, and Knowledge for Digital Lives: Proceedings (19th International Conference on Asia-Pacific Digital Libraries, ICADL 2017, Bangkok, Thailand, November 13-15 2017), 104-116. 
Стокић Симончић Г. и др. „Информациона писменост наставника и сарадника на Универзитету у Београду“, 12-23

Универзитет се налази међу 300 најбољих светских универзитета, пошто је 2017. рангиран између 201. и 300. места (The 2017 Academic Ranking of World Universities - ARWU). ${ }^{10}$

\section{Узорак}

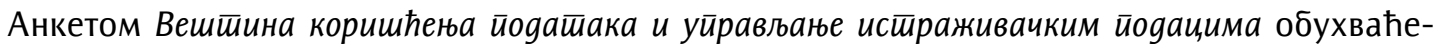
но је 15 факултета Универзитета у Београду (Биолошки, Географски, Економски, Електротехнички, Факултет ветеринарске медицине, Факултет драмских уметности, Факултет организационих и Факултет политичких наука, Фармацеутски, Филозофски, Филолошки, Физички, Правни, Машински и Рударско-геолошки факултет), Универзитетска библиотека „Светозар Марковић“, Институт за савремену историју, као и докторанти на Катедри за библиотекарство и информатику Филолошког факултета.

Укупан број послатих анкета износи 692 и оне су упућене на адресе 367 особа мушког и 325 женског пола. Одговорило је 159 (22,9\%) испитаника, и то 85 (53,46\%) - попунивши комплетну анкету и $74(46,54 \%)$ који су је оставили недовршену. Упркос напорима анкетара да у истраживању полови буду равноправно заступљени, структура запослених наметнула је већи број мушкараца. Но, када су у питању анкетирани, испоставило се да су жене биле спремније да учествију у истраживању, и када су потпуне и када су непотпуне анкете у питању. Индикативно је, такође, да су број потпуних и непотпуних анкета сасвим приближни те да се интересантни закључци могу извести и анализом питања која су остала без одговора.

Анкета се састојала од два сегмента: „Демографских информација“ (5 питања) и „Свести о питањима управљања подацима" (20).

На анкету је одговорило 60 особа женског пола (70,5\%) и 25 мушког $(29,5 \%)$, сви из Републике Србије. ${ }^{11}$

При навођењу тренутног занимања, чак 74 испитаника (87\%) је одговорило да припада академском особљу, 9 (10,5\%) студентима истраживачима, а 2 особе $(2,5 \%)$ су дале одговор под „остало“, тј докторанд и библиотекар.

Што се старосне структуре тиче, 1 испитаник (1\%) је у годинама између 18 и 25, 19 (22,5\%) од 26 до 35, 28 (33\%) 36-45, 22 (26\%) 46-55, 14 (16,5\%) 56-65, док је једна особа (1\%) старија од 65 година. У складу са годинама живота испитаника, научноистраживачким радом се баве: 13 (15,5\%) мање од 5 година, 18 (21,5\%) 5-10, 12 (14\%) 11-15, 15 (17,5\%) 16-20, а 27 (32\%) дуже од 20 година. Према старосној структури, највише одговора дали су испитаници између 36 и 45 година, али су, према научном стажу, најбројнији они који се преко 20 година баве науком.

Списак научних дисциплина у оквиру којих делују испитаници био је понуђен, а сумирање одговора извршено је у складу са њиховом поделом у Web of Science (WoS) бази података. Тако су добијени подаци о заступљености појединих грана науке у анкети.

Табела 1. Научне дисциплине према Web of Science - WoS бази података

\begin{tabular}{|l|l|}
\hline Научна дисциплина & Број испитаника \\
\hline Природне науке (Sciences) & $37(43,5 \%)$ \\
\hline Друштвене науке (Social sciences) & $19(22,5 \%)$ \\
\hline Хуманистичке науке (Humanities) & $20(23,5 \%)$ \\
\hline Остало & $9(10,5 \%)$ \\
\hline
\end{tabular}

\footnotetext{
10 Универзитет у Београду међу 300 најбољих светских универзитета, http://bg.ac.rs/sr/mediji/rank.php (преузето 8. 3. 2018).

11 У наредном тексту, ради прегледности, резултати ће бити заокруживани на пола броја.
} 
Стокић Симончић Г. и др. „Информациона писменост наставника и сарадника на Универзитету у Београду“, 12-23

Извесно изненађење за анкетаре представљала је чињеница да међу испитанима нема више млађих истраживача, али и да су истраживачи из области друштвених и хуманистичких наука показали завидну спремност да учествују у анкети. Увидом у одговоре под „Остало“ лако је утврдити да овим научним групацијама припадају и испитаници из те категорије. Коментар, међутим, заслужује изузетно мали одзив на анкету, на коју је у потпуности одговорило тек $12,5 \%$ особа којима је она послата. И док је, на пример, запосленима на Медицинском факултету било немогуће упутити анкету јер се електронске адресе наставника и сарадника не налазе на веб-страници факултета, дотле је највећи број анкета послат на Факултет организационих наука (160), да би на њу одговорило тек 8 (5\%) испитаника и то 3 непотпуно! Ниједан потенцијални испитаник са Факултета политичких наука и са Физичког факултета није нашао за сходно да попуни анкету, али је зато одзив са Филолошког факултета, матичне институције анкетара, убедљиво најбољи и износи 30\%, не рачунајући чак и један број докторанада који су такође анкетирани. ${ }^{12}$

\section{Уӣрављање исйраживачким ӣоgащима}

Други део анкете „Свест о проблемима управљања подацима” може се поделити на неколико сегмената који се односе на: 1. Врсту и обим коришћених и произведених података; 2. Праксу коришћења, проналажења, похрањивања и описивања; 3. Ставове према дељењу података; 4. Став о улози институција у Плану за управљање подацима (ПУП); и 5. Искуство у обуци и спремност за учествовање у обучавању за ПУП. ${ }^{13}$

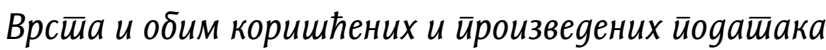

На питање „Молимо Вас да наведете тип података који иначе користите за истраживање“, где је било могуће дати више одговора, највећи број испитаника се изјаснио за стандардне документе Офис (Office) пакета (текст, табела, презентација итд.), чак 79 (93\%). Потом су наводили податке засноване на интернету и вебу (веб-странице, имејлови, блогови, друштвене мреже итд.) - 67 (79\%), слике (JPEG, GIF, TIFF, PNG итд.) - 51 (60\%), архивиране (ZIP, RAR, ZAR итд.) - 43 (50,5\%), структуриране научне и статистичке (нпр. SPSS, GIS итд.) - 40 (47\%), аналогне податке (папир, филмови, слајдови, артефакти итд.) - 37 (43,5\%), базе података (нпр. у Access-y, Oracle-y, MySQL-у итд.) - 25 (29,5\%), звучне фајлове - 22 (26\%), софтверске апликације (моделирање алата, едитори, компајлери итд.) -22 (26\%). Испитаници најмање користе конфигурационе податке (подешавање параметара, евиденције, складиштени фајлови итд.) - 16 (19\%), кодирани текст (XML, SGML итд.) - 13 (15,5\%), структурирану графику (CAD, CAM, VRML итд.) - 12 (14\%), изворни код (Java, C, C++ итд.) - $11(13 \%)$ и сирове (машинске - генерисане) податке - 9 (10,5\%).

Са тиме у вези, било је занимљиво поређење резултата истраживања који су илустровани питањем „Који тип података настаје као производ Вашег истраживања?“, уз могућност давања више од једног одговора. Испитаници су, такође у највећем броју ( 80 - 94\%), одабрали стандардне документе Офис (Office) пакета (текст, табела, презентација итд.). Редослед врста података које су производ истраживања разликује се од оних које се користе у научноистраживачком раду, па тако примат добијају: структурирани научни и статистички подаци (нпр. SPSS, GIS итд.) - 33 (39\%), слике (JPEG, GIF, TIFF, PNG итд.) - 31 (36,5\%), аналогни подаци (папир, филмови, слајдови, артефакти итд.) - 21 (24,5\%), а тек онда подаци засновани на интернету и

\footnotetext{
12 На основу овога могао би се, можда, извући закључак о осећају колегијалности који постоји унутар факултета, али се не доживљава као императив када су у питању други факултети на Универзитету.

13 Подела је учињена према Sonja Špiranec and Denis Kos, Nav. delo.
} 
вебу (веб-странице, имејлови, блогови, друштвене мреже итд.) - 18 (21\%), архивирани подаци (ZIP, RAR, ZAR итд.) - 14 (16,5\%), базе података (нпр. у Access-y, Oracle-y, MySQL-y итд.) - 10 (12\%), софтверске апликације (моделирање алата, едитори, компајлери итд.) - 10 (12\%), изворни код (Java, C, C++ итд.) - 10 (12\%). Најмањи број испитаника определио се за структурирану графику (CAD, CAM, VRML итд.) - 8 (9,5\%), конфигурационе податке (подешавање параметара, евиденције, складиштени фајлови итд.) - 8 (9,5\%), кодирани текст (XML, SGML итд.) - 7 (8\%), звучне фајлове - 5 (6\%) и сирове (машинске - генерисане) податке - 5 (6\%).

Када су упитани о обиму података које користе за истраживање, где је требало изабрати само један од понуђених одговора, испитаници су одговорили: GB (гигабајт) - 44 (52\%), MB (мегабајт) - 37 (43,5\%), ТВ (терабајт) - 4 (5\%). Али када је требало изразити обим података који настаје као резултат истраживања испитаници су се определили за МВ (мегабајт) -51 $(60 \%)$, GB (гигабајт) - $30(35,5 \%)$ и ТВ (терабајт) - 4 (4,5\%). То показује да се више података преузима, него што се објављује.

\section{Пракса коришћења, ирроналажења, ӣохрањивања и ойисивања}

На питање „Како најчешће добијате податке за своја истраживања?", са могућношћу избора више одговора, испитаници су наводили да су то више познатих извора - 55 (64,5\%), да стварају нове податке - 51 (60\%), добијају их од сопствене истраживачке мреже (или личне/ професионалне) везе - 41 (48\%), или од сопственог истраживачког тима/групе на универзитету - 37 (43,5\%). Пет одговора под „Остало“ (6\%) подразумевало је веб-изворе, базу Р3С (Републички завод за статистику), институционалне збирке и/или њихове онлајн базе података, претежно изван Србије, и друге базе доступне на интернету. Ниједан испитаник није одговорио да користи податке „увек из једног познатог извора“.

Начин њиховог коришћења дефинисали су: „Са мало труда око чишћења и/или модификације“ - 43 (50,5\%) и „Након доста времена и труда да се учине употребљивим за пројекат“ - 33 (39\%). Велики број, чак 31 (36,5\%), наводи да их употребљава „Као што су наведени, без икаквих проблема", а постоје и они који не користе податке које добијају од других (спољних) извора - 9 (10,5\%).

Место чувања података истраживања у највећем броју је сопствени рачунар (таблет, спољни диск, итд.) - 84 (99\%), а тек онда „Облак“ (Cloud) - 25 (29,5\%), централни сервер (репозиторијум) универзитета - 6 (7\%) и „ван репозиторијума“ - 3 (3,5\%). Одговора под „Остало“ било је 5 (6\%) и подразумевали су: дропбокс (dropbox), драјв (one drive), гугл драјв (google drive). Испитаници су одговорили: „Део података је такође код других истраживача који учествују у истраживањима“ и „На серверима факултета“.

На питање „Да ли обично додељујете било какве додатне информације Вашим истраживачким подацима?", на које је било омогућено више опција, испитаници су навели административне информације (нпр. стваралац, датум креирања, назив документа, приступ условима/ ограничењима итд.) - 53 (62,5\%), информације које упућују на ствараоца, финансијера, наслов пројекта или ИД пројекта, кључне речи итд. - 41 (48\%). Велики број одговора је гласио „Не, ја не додељујем додатне информације својим истраживачким подацима." - 21 (24,5\%). Навођени су и опис датотеке (нпр. структура фајла/података, област ознаке/описа, правила апликације итд.) - 20 (23,5\%) и техничке информације (нпр. формат датотеке, величина фајла, софтвер/хардвер потребан за коришћење итд.) - 14 (16,5\%).

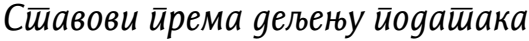

Важан сегмент упитника била је и сарадња са другим истраживачима, па су испитаници у највећем броју навели да сарађују са онима који су у истом тиму - 65 (76,5\%). Сарадњу са колегама у другим институцијама одабрало је њих 41 (48\%), а оне који су на истом универзитету - 27 (32\%). Чак 9 (10,5\%) испитаника је навело да не сарађује са другим истраживачима. 
Питање доступности истраживачких података, са више подразумеваних одговора, донело је следеће резултате: „Моји подаци су доступни на захтев“ - 48 (56,5\%), „Моји подаци су доступни свима" - 32 (37,5\%), "Моји подаци су доступни само мом истраживачком тиму“ - 30 $(35,5 \%)$, Приступ мојим подацима је ограничен (нпр. доступни су само делови података)“ $-16(19 \%)$ и "Моји подаци нису доступни ником другом" - 1 (1\%). Овакви резултати не иду у прилог потреби и жељи за универзалном доступношћу података.

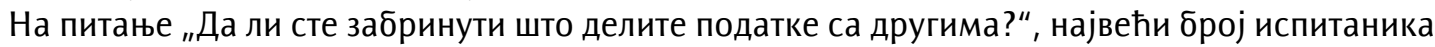
је одговорио да није - 60 (70,5\%). Њих 19 (22,5\%) изразило је своју забринутост због могуће злоупотребе података, а 18 (21\%) због погрешног тумачења. Правна и етичка питања као извор бриге навело је 11 (13\%), непостојање одговарајуће политике и заштите права такође 11 $(13 \%)$, а недостатак средстава (техничких, финансијских, личних итд.) - 5 (6\%). Два (2,5\%) истраживача су одабрала одговор „Бојим се да ћу изгубити истраживачку предност коју ми ти подаци дају“. Три одговора (3,5\%) сврстана под „Остало“ гласила су: „Нисам забринут за део података које делим у склопу договорене научне сарадње“, „Резултат над подацима је од значаја, анализа одговарајућим методама, а не и сами подаци које користимо“ и „Зависи од врсте података". Ово питање је такође подразумевало могућност избора више одговора. Иако је преко $70 \%$ испитаника исказало да није забринуто због дељења података, готово подједнак број је ипак изразио неку врсту бриге. Ови подаци врло јасно показују да у научноистраживачкој заједници постоји оправдани страх од злоупотребе података.

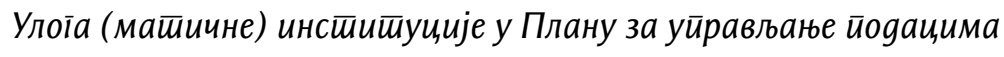

Плану за управљање подацима (Data management plan -DMP) посвећена је у анкети посебна пажња. Цео низ питања постављен је са циљем да на нивоу матичне институције, али и на индивидуалном плану, утврди обавештеност и упућеност истраживача у ову проблематику.

Табела 2. Питања у вези са Планом управљања подацима (ПУП)

\begin{tabular}{|c|c|c|c|c|}
\hline Питање & Да & $\begin{array}{l}\text { Нисам сигуран } \\
\text { /сигурна }\end{array}$ & $\mathrm{He}$ & $\begin{array}{l}\text { Без } \\
\text { одговора }\end{array}$ \\
\hline $\begin{array}{l}\text { Да ли Ваша установа има план за } \\
\text { управљање подацима (ПУП)? }\end{array}$ & $3(3,5 \%)$ & $60(70,5 \%)$ & $22(26 \%)$ & 0 \\
\hline $\begin{array}{l}\text { Да ли сте икад користили ПУП у својим } \\
\text { истраживањима? }\end{array}$ & $3(3,5 \%)$ & $15(17,5 \%)$ & 67 (79\%) & 0 \\
\hline $\begin{array}{l}\text { Да ли имате ПУП за Ваш текући } \\
\text { истраживачки пројекат/пројекте? }\end{array}$ & $6(7 \%)$ & $22(26 \%)$ & $57(67 \%)$ & 0 \\
\hline $\begin{array}{l}\text { Да ли мислите да ПУП заиста помаже } \\
\text { истраживачима у } \\
\text { управљању истраживачким подацима? }\end{array}$ & $16(19 \%)$ & $62(73 \%)$ & $7(8 \%)$ & 0 \\
\hline Да ли сте упознати са појмом метаподаци? & $60(70,5 \%)$ & $10(12 \%)$ & $15(17,5 \%)$ & 0 \\
\hline $\begin{array}{l}\text { Да ли мислите да би формална обука о } \\
\text { метаподацима била } \\
\text { корисна за управљање истраживачким } \\
\text { подацима? }\end{array}$ & $62(73 \%)$ & $20(23,5 \%)$ & $3(3,5 \%)$ & 0 \\
\hline $\begin{array}{l}\text { Да ли Ваш универзитет има прописан скуп } \\
\text { метаподатака за отпремање података у } \\
\text { складиште/репозиторијум? }\end{array}$ & $3(3,5 \%)$ & $73(86 \%)$ & $9(10,5 \%)$ & 0 \\
\hline
\end{tabular}




\begin{tabular}{|c|c|c|c|c|}
\hline Питање & Да & $\begin{array}{l}\text { Нисам сигуран } \\
\text { /сигурна }\end{array}$ & $\mathrm{He}$ & $\begin{array}{l}\text { Без } \\
\text { одговора }\end{array}$ \\
\hline $\begin{array}{l}\text { Да ли Ваша истраживачка заједница } \\
\text { користи/препоручује неки стандардни } \\
\text { систем именовања фајлова? }\end{array}$ & $4(4,5 \%)$ & $40(47 \%)$ & 41 (48\%) & 0 \\
\hline $\begin{array}{l}\text { Да ли Ваш универзитет има стандардни/ } \\
\text { доследан систем именовања фајлова? }\end{array}$ & $2(2,5 \%)$ & $49(57,5 \%)$ & 34 (40\%) & 0 \\
\hline $\begin{array}{l}\text { Да ли користите неки стандардни стил за } \\
\text { цитирање истраживачких података? }\end{array}$ & 68 (80\%) & $9(10,5 \%)$ & $8(9,5 \%)$ & 0 \\
\hline $\begin{array}{l}\text { Да ли сте знате шта подразумева концепт } \\
\text { DOI (Digital Object Identifier - DOI)? }\end{array}$ & $60(70,5 \%)$ & 11 (13\%) & $14(16,5 \%)$ & 0 \\
\hline $\begin{array}{l}\text { Да ли Ваш универзитет препоручује неке } \\
\text { специфичне смернице за цитирање } \\
\text { (АРА, Харвард итд.)? }\end{array}$ & 35 (41\%) & 28 (33\%) & $22(26 \%)$ & 0 \\
\hline $\begin{array}{l}\text { Да ли сте добили неки јединствени } \\
\text { идентификатор истраживача } \\
\text { (као што је ORCID = отворени ID } \\
\text { истраживача и сарадника)? }\end{array}$ & 39 (46\%) & 16 (19\%) & $30(35,5 \%)$ & 0 \\
\hline $\begin{array}{l}\text { Да ли Ваш универзитет активно охрабрује } \\
\text { да делите податке у режиму отвореног } \\
\text { приступа (OA)? }\end{array}$ & $13(15,5 \%)$ & $49(57,5 \%)$ & $23(27 \%)$ & 0 \\
\hline $\begin{array}{l}\text { Да ли сте упознати са захтевима } \\
\text { финансијера Вашег универзитета } \\
\text { у погледу складиштења података? }\end{array}$ & $3(3,5 \%)$ & $22(26 \%)$ & $60(70,5 \%)$ & 0 \\
\hline
\end{tabular}

Индикативно је да највећи број питања типа „Да ли ваш универзитет има....” даје позитивне одговоре у сасвим малом проценту. Највећи број анкетираних истраживача није сигуран да ли установа у којој ради поседује План управљања подацима (ПУП), нити прописан скуп метаподатака за отпремање података у репозиторијум. Такође изражавају своју несигурност када су упитани да ли Универзитет има доследан систем именовања фајлова и да ли су охрабрени да деле податке у режиму отвореног приступа. ПУП нити су користили, нити користе у свом раду, а нису ни сигурни да ли он помаже у управљању истраживачким подацима. Готово половина се изјашњава да истраживачка заједница не користи и не препоручује доследан систем именовања фајлова. Већина такође не познаје захтеве финансијера у погледу складиштења података. Позитиван резултат дала су питања у вези са појмом метаподатака, јер га познаје већина испитаника и сматра да би формална обука била корисна за управљање истраживачким подацима. Највећи број користи неки стандардни начин цитирања, а тврди и да Универзитет препоручује одређене стилове. Изјашњавају се и да су упознати са DOI (Digital Object Identifier) концептом, а поседују неки јединствени идентификатор истраживача (као што је ORCID = отворени ID истраживача и сарадника). Готово је немогуће не уочити диспропорцију између индивидуалног и колективног у овом сету одговора, као да су истраживачи у огромном проценту необавештени о дешавањима на нивоу Универзитета. 
Табела 3. Питања у вези са управљањем подацима у истраживачком раду

\begin{tabular}{|c|c|c|c|c|c|c|}
\hline $\begin{array}{l}\text { Колико често } \\
\text { практикујете следеће: }\end{array}$ & Скоро увек & Често & Понекад & Ретко & Никад & $\begin{array}{l}\text { Без } \\
\text { одговора }\end{array}$ \\
\hline $\begin{array}{l}\text { Користите метаподатке } \\
\text { за означавање својих } \\
\text { података }\end{array}$ & $3(3,5 \%)$ & $10(12 \%)$ & $21(24,5 \%)$ & $15(17,5 \%)$ & $36(42,5 \%)$ & 0 \\
\hline $\begin{array}{l}\text { Користите сопствене } \\
\text { ознаке и метаподатке } \\
\text { или ознаке и } \\
\text { метаподатке свог } \\
\text { истраживачког тима }\end{array}$ & $6(7 \%)$ & $19(22,5 \%)$ & 17 (20\%) & 10 (12\%) & 33 (39\%) & 0 \\
\hline $\begin{array}{l}\text { Користите скупове } \\
\text { података који су } \\
\text { означени метаподацима }\end{array}$ & $5(6 \%)$ & $9(10,5 \%)$ & $21(24,5 \%)$ & $15(17,5 \%)$ & 35 (41\%) & 0 \\
\hline $\begin{array}{l}\text { Користите конвенције } \\
\text { или стандарде за } \\
\text { именовање фајлова }\end{array}$ & $4(4,5 \%)$ & $20(23,5 \%)$ & $18(21 \%)$ & $8(9,5 \%)$ & 35 (41\%) & 0 \\
\hline $\begin{array}{l}\text { Имате различите } \\
\text { верзије истих скупова } \\
\text { података }\end{array}$ & $12(14 \%)$ & 27 (32\%) & $24(28 \%)$ & $10(12 \%)$ & $12(14 \%)$ & 0 \\
\hline $\begin{array}{l}\text { Користите систем/ } \\
\text { технике за контролу } \\
\text { верзија, како бисте } \\
\text { лакше препознали } \\
\text { одређену верзију }\end{array}$ & $16(19 \%)$ & $20(23,5 \%)$ & $19(22,5 \%)$ & $11(13 \%)$ & $19(22,5 \%)$ & 0 \\
\hline $\begin{array}{l}\text { Цитирање } \\
\text { истраживачких података }\end{array}$ & $54(63,5 \%)$ & $16(19 \%)$ & $11(13 \%)$ & $1(1 \%)$ & $3(3,5 \%)$ & 0 \\
\hline $\begin{array}{l}\text { Радите са подацима } \\
\text { који су обично у јавном } \\
\text { домену }\end{array}$ & $32(37,5 \%)$ & $23(27 \%)$ & $18(21 \%)$ & $8(9,5 \%)$ & $4(4,5 \%)$ & 0 \\
\hline $\begin{array}{l}\text { Радите са подацима } \\
\text { којима је приступ } \\
\text { ограничен }\end{array}$ & $5(6 \%)$ & $14(16,5 \%)$ & $40(47 \%)$ & $18(21 \%)$ & $8(9,5 \%)$ & 0 \\
\hline
\end{tabular}

Одговарајући на питања у вези са управљањем научноистраживачким подацима, већи део чланова академске заједнице тврди да никада не користи метаподатке за означавање својих података, ознаке и метаподатке сопственог истраживачког тима, нити скупове података означене метаподацима, па ни конвенције и стандарде за именовање фајлова. Наведени резултати могли би се укрстити нпр. са податком да је 70\% истраживача упознато са појмом метаподатака (Табела 2), па да се упитамо, рецимо, да ли је могуће да већина њих не ставља наслов текста, име аутора, кључне речи у име фајла, или нпр. датум преузимања. Или је, ипак, реч о томе да не схватају у целини на шта се ова питања односе? Даље, изјаснили су се да понекад и често имају различите верзије истих скупова података, као и да користе системе и технике за контролу, ради лакшег препознавања одређене верзије. Већина цитира истраживачке податке, али постоји и оних 17\% који то раде тек понекад, ретко или никад. Највећи број истраживача користи податке у јавном домену: сасвим је мали проценат оних који их никада не користе и који скоро увек раде са подацима којима је приступ ограничен, што би се могло објаснити и недовољним владањем техникама за приступ подацима тог типа. 
Табела 4. Питања у вези са дељењем и чувањем података

\begin{tabular}{|c|c|c|c|c|c|c|}
\hline $\begin{array}{l}\text { У којој мери се слажете или } \\
\text { не слажете са следећим } \\
\text { ставкама? }\end{array}$ & $\begin{array}{l}\text { Потпуно } \\
\text { се } \\
\text { слажем }\end{array}$ & $\begin{array}{l}\text { Слажем } \\
\text { се }\end{array}$ & $\begin{array}{l}\text { Нити се } \\
\text { слажем, } \\
\text { нити } \\
\text { се не } \\
\text { слажем }\end{array}$ & $\begin{array}{l}\text { Не } \\
\text { слажем } \\
\text { се }\end{array}$ & $\begin{array}{l}\text { Уопште } \\
\text { се не } \\
\text { слажем }\end{array}$ & $\begin{array}{l}\text { Без } \\
\text { одговора }\end{array}$ \\
\hline $\begin{array}{l}\text { Упознат сам са захтевима за } \\
\text { отвореним приступом }\end{array}$ & $23(27 \%)$ & $26(30,5 \%)$ & $25(29,5 \%)$ & $9(10,5 \%)$ & $2(2,5 \%)$ & 0 \\
\hline $\begin{array}{l}\text { У реду је и спреман } \\
\text { сам да поделим своје } \\
\text { истраживачке податке са } \\
\text { другима }\end{array}$ & $25(29,5 \%)$ & $36(42,5 \%)$ & 19 (22,5\%) & $5(6 \%)$ & 0 & 0 \\
\hline $\begin{array}{l}\text { Не предвиђам никакве } \\
\text { проблеме због тога што } \\
\text { делим своје истраживачке } \\
\text { податке са другима }\end{array}$ & 16 (19\%) & $36(42,5 \%)$ & $22(26 \%)$ & $9(10,5 \%)$ & $2(2,5 \%)$ & 0 \\
\hline $\begin{array}{l}\text { Мислим да етика података } \\
\text { може постати питање када } \\
\text { се истраживачки подаци } \\
\text { деле са другима }\end{array}$ & 7 (8\%) & $42(49,5 \%)$ & $25(29,5 \%)$ & 10 (12\%) & $1(1 \%)$ & 0 \\
\hline $\begin{array}{l}\text { Желео бих да чувам } \\
\text { скупове података који су } \\
\text { резултат мог истраживања, } \\
\text { чак и изван трајања } \\
\text { пројекта }\end{array}$ & 24 (28\%) & 33 (39\%) & $18(21 \%)$ & 7 (8\%) & $3(3,5 \%)$ & 0 \\
\hline $\begin{array}{l}\text { Сваки универзитет треба } \\
\text { да има план за управљање } \\
\text { подацима }\end{array}$ & 40 (47\%) & $30(35,5 \%)$ & $13(15,5 \%)$ & $1(1 \%)$ & $1(1 \%)$ & 0 \\
\hline $\begin{array}{l}\text { Сваки универзитет треба } \\
\text { да има прописан сет } \\
\text { метаподатака за отпремање } \\
\text { података у складиште } \\
\text { (репозиторијум) }\end{array}$ & $37(43,5 \%)$ & $32(37,5 \%)$ & $13(15,5 \%)$ & $1(1 \%)$ & $2(2,5 \%)$ & 0 \\
\hline $\begin{array}{l}\text { Универзитет треба да } \\
\text { препоручи и користи систем } \\
\text { за именовање фајлова }\end{array}$ & 34 (40\%) & 35 (41\%) & $13(15,5 \%)$ & $1(1 \%)$ & $2(2,5 \%)$ & 0 \\
\hline
\end{tabular}

Различити одговори су пристигли и на питања у вези са дељењем и чувањем података. Нешто више од половине испитаника изјаснило се да је упознато са захтевима за отвореним приступом и да је спремно да подели своје истраживачке податке са другима. Они не предвиђају неке проблеме када је у питању дељење података, па ипак половина њих сматра да етичност може постати питање када се истраживачки подаци деле са другима. Такође, више од половине жели да чува скупове података који су резултат сопственог истраживања и по завршетку одређеног пројекта. Највећи број сматра да Универзитет треба да има план за управљање подацима, прописан сет метаподатака за њихово отпремање у складиште (репозиторијум) и да ова институција треба да препоручи и користи систем за именовање фајлова.

У складу са тиме, на питање „По Вашем мишљењу, ко треба да плати за складиштење и јавни приступ подацима које сте Ви креирали?“, са више опција, испитаници су навели Универзитет - 52 (61\%), потом неко национално тело - 43 (50,5\%) и финансијера - 31 (36,5\%). Најмањи 
број, њих 11 (13\%), сматра да би сами требало да плате складиштење и јавни приступ подацима. Изабравши одговор „Остало“ - 4 (4,5\%) испитаника су дала следеће одговоре: „Онај коме су потребни... у неким ситуацијама“, „Питање непрецизно јер за складиштење својих података истраживач скоро увек плаћа сам“ и „Не знам“ (2 одговора). По мишљењу већине припадника академске заједнице, Универзитет је место на којем би требало да се чувају подаци како би се омогућио дугорочни приступ (65-76,5\%). Један број њих се одлучио за друге опције: „У спољној меморији (екстерном складишту), неплаћено“ - 31 (36,5\%), „Код онога ко финансира институцију" - 25 (29,5\%) и "У спољној меморији (екстерном складишту), плаћено“ - 15 (17,5\%). Одабравши опцију „Остало“ - 2 (2,5\%) испитаника су дала одговор да не знају.

\section{Обука за уйрављање йодацима}

У последњем сегменту анкете, испитаници су одговарали на питања о искуству у обуци за ПУП. Већина њих $(70-82,5 \%)$ се изјаснила да није имала никакве обуке. Они који јесу, наводили су следеће области: стилови навођења података - 12 (14\%), метаподаци - 8 (9,5\%), план за управљање подацима - 1 (1\%), систем за именовање фајлова - 1 (1\%) и контрола верзија скупова података - 1 (1\%).

На постављено питање о жељи да се обуче из одређених области, наводили су: план за управљање подацима - 52 (61\%), метаподатке - 46 (54\%), систем за именовање фајлова 44 (52\%), контролу верзија сетова података - 36 (42,5\%) и стилове навођења података - 38 $(44,5 \%)$. Прилично велики број испитаника, чак $20(23,5 \%)$ није показао заинтересованост за било какву обуку. Опцију „Остало“ изабрало је 4 (4,5\%) и дало следеће одговоре: „Мислим да то треба да раде запослени у институтима“, "Уколико би се уводио стандард који морамо да користимо, онда би требало да постоји и обука“, „Не знам“ и „Можда све по мало“.

На крају анкете испитаници су замољени да напишу свој коментар у вези са управљањем подацима. Без одговора је остало 78 (91,5\%), док је 7 (8\%) дало следеће одговоре: „Подржавам“, „Професори су превише оптерећени обавезама у настави, научним пројектима, сопственим истраживањима и активностима изван факултета и јако је тешко наћи довољно времена за усавршавање у области управљања подацима иако би то било веома корисно“, "За неке од појмова и концепата нисам чула, и мислим да би истраживачима, чак и нама у друштвеним наукама, едукација на ове теме била корисна и пожељна“, „Обједињени курс; ово дељено нема смисла јер су све области битне“, „Немам коментар“, „Постоји веома изражена специфичност типова података чак у оквиру сродних (у мом случају биолошких) дисциплина, тако да су нека од питања донекле ирелевантна за праксу рада са подацима“, „Било је пар нејасних питања. Друга ствар је као што знате да су факултети правна лица и да смо ми као наставници искључиво упућени на факултете. Мислим да би Универзитет као такав морао да буде много боље организован и да буде стварно једно кровно правно тело“.

\section{Непотпуне анкете}

Као што је већ поменуто, од 159 попуњених анкета непотпуних је било 74, што чини чак 46,5\%. Интересантно је приметити да је на питања из сета "Демографских информација“ стигао по 31 одговор, будући да је на свако по 9 (22,5\%) испитаника изабрало опцију „Без одговора“. Ово би могло да значи да анкети чак ни у пољу најопштијих информација није приступљено са озбиљношћу и стрпљењем.

Други део анкете који су чинила питања из области „Свести о питањима управљања подацима“ попуњавало је још мање испитаника. Занимљиво је да број није опадао како је одмицала анкета, него по врсти питања. Тако је, на питања о типу података које користе за истраживање, а који тип настаје из њихових истраживања, одговорило од 15 до 26 испитаника, али, на пример, на сет питања о коришћењу ПУП-а, о управљању подацима у научноистраживачком 
раду или о дељењу и чувању података само 6, односно 7. Ако се узме у обзир да је преко 70\% изабрало опцију „Без одговора“, на ову групу питања је одговорио један, понекад два испитаника. Овом приликом није учињена детаљнија анализа одговора јер би се дошло до неравномерних и непоузданих података.

Анкетари су, заправо, имали дилему да ли се у случају непотпуних анкета радило о нестрпљењу да им се посвете време и пажња, или о темељном непознавању истраживаног подручја. Ово би, са анализираним резултатима потпуних анкета, дало прилично поразну слику о односу академског особља према плановима за управљање подацима и његовој информационој писмености и оспособљености за баратање истраживачким подацима, односно њиховом проналажењу, вредновању и коришћењу.

\section{Закључак}

Узорак од 85 испитаника из различитих научних области који су учествовали у анкети Вe-

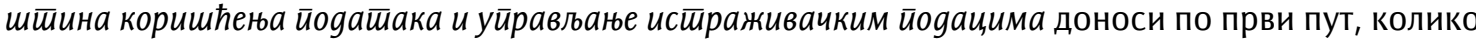
нам је познато, резултате једног међународног - европског истраживања информационе писмености академског особља у које се Србија укључила. Истраживачи са Универзитета у Београду - у највећем проценту наставници - одговарали су онлајн на 24 питања конципирана тако да открију навике, обавештеност и вештину из домена data literacy, а сама информациона писменост третирана је у најширем смислу - као појам који укључује и оспособљеност за рад са подацима као квинтесенцијом истраживачког рада. С друге стране, саопштени су резултати који представљају тек сумарни преглед исказаних ставова и који би се могли додатно тумачити нпр. с обзиром на научне области којима припадају истраживачи, или на звања, тј. године бављења научним радом. Но, релативно мали узорак овом је приликом анкетаре навео да од такве анализе одустану.

Спроведено истраживање потврдило је полазну претпоставку анкетара да истраживачи на Универзитету у Београду имају потребу за додатном обуком у домену коришћења и руковања истраживачким подацима. Иако су показали обавештеност, они ипак нису потврдили суштинско разумевање појединих концепата из домена опште доступности публикација и отворене науке. У односу на кровну институцију, имплицитно се очитовала „усамљеност“ истраживача и слаба „видљивост“ Универзитета, упоредо са мањком институционалне инфраструктуре (политике, сервиси, средства, репозиторијуми, процедуре). У најширем смислу, као неопходност се показала промена организационе културе Универзитета.

\section{Литература и извори:}

1. ALA Presidental Committee on Information Literacy. Final Report. 1989. http://www.ala.org/acrl/ publications/whitepapers/presidential (preuzeto 24. 12. 2017).

2. Chowdhury, Gobinda, Joumana Boustany, Serap Kurbanoğlu, Yurdagül Ünal and Geoff Walton. "Preparedness for Research Data Sharing: A Study of University Researchers in Three European Countries". In Digital Libraries: Data, Information, and Knowledge for Digital Lives: Proceedings, 104-116. 19th International Conference on Asia-Pacific Digital Libraries, ICADL 2017, Bangkok, Thailand, November 13-15 2017.

3. IFLA. Information Literacy Section. https://www.ifla.org/information-literacy (preuzeto 15. 11. 2017).

4. Koltay, Tibor. "Big data, big literacies?". Čitalište: naučni časopis za teoriju i praksu bibliotekarstva Godina 13, broj 24 (maj 2014): 3-8.

5. Stokić Simončić, Gordana i Željko Vučković. "Information Literacy in Serbia: Initiatives and Strategies". Studies in Informatics and Control (SIC) Volume 19, number 2 (June 2010): 177-184. 
Стокић Симончић Г. и др. „Информациона писменост наставника и сарадника на Универзитету у Београду“, 12-23

6. Špiranec, Sonja and Denis Kos. "Data Literacy and Research Data Management: the Croatian State of Affairs". In ECIL 2017, CCIS.Serap Kurbanoğlu, Joumana Boustany, Sonja Špiranec, Esther Grassian, Diane Mizrachi and Loriene Roy, eds. Heidelberg: Springer Verlag. Dostupno i na http://link.springer. com/ (preuzeto 9. 3. 2018).

7. Špiranec, Sonja i Mihaela Banek Zorica. Informacijska pismenost-Teorijski okvir i polazišta. Zagreb: Zavod za informacijske studije, 2008.

8. Univerzitet u Beogradu među 300 najboljih svetskih univerziteta. http://bg.ac.rs/sr/mediji/rank.php (preuzeto 8. 3. 2018).

\title{
Information Literacy of Professors and Associates at the University of Belgrade
}

\begin{abstract}
Summary
This paper presents the results of the research conducted at the University of Belgrade in 2017, with the aim of determining the level of information literacy of professors and associates, by examining their ability to manage research data. Data on the habits of researchers (professors, associates, PhD students, librarians) were collected in the identical online survey (Data Literacy and Research Data Management Research) in the academic environments of a number of European countries concurrently, in order to allow a comparative overview of the issues.

A total of 692 questionnaires were sent. They were addressed to 367 male and 325 female recipients. The researchers ( 85 of them), mostly professors and mostly women, replied online to 24 questions: 5 containing "demographic information" and 20 concerning "awareness of data management issues". The reported results provide only an overview of the expressed attitudes. They could be further interpreted e.g. with regard to the scientific fields to which the researchers belong, or to their titles, i.e. years of the scientific work. However, a relatively small sample of respondents made the surveyors abandon such an analysis on this occasion.

The research results confirm the initial assumption of surveyors that the researchers at the University of Belgrade need additional training in the field of work with research data. Although informed of the subject, they still have not demonstrated the essential understanding of certain concepts in the field of general availability of publications and open science. In relation to the umbrella institution, the "loneliness" of the researchers and the poor "visibility" of the University, along with the lack of institutional infrastructure (policies, services, resources, repositories, procedures), were implicitly manifested. In the broadest sense, the change in the organizational culture of the University has proved to be a necessity.
\end{abstract}

Keywords: University of Belgrade, professors, associates, researchers, librarians, habits, information literacy, survey, Data Literacy and Research Data Management Research, infrastructure 


\section{(2) $\odot \Theta \Theta$}

Информациона писменост наставника и сарадника на Универзитету у Београду bу Гордана Стокић Симончић, Драгана Сабовљев is licensed under a Creative Commons Attribution-NonCommercialNoDerivatives 4.0 International License. 